\title{
Tests of biological activity of metabolites from Penicillium expansum 〈Link $>$ Thom various isolates
}

\author{
HALINA BORECKA ${ }^{1 \cdot}$ MARIOLA PYTEL ${ }^{1,}$ MARIE FENNEY ${ }^{2}$
}

${ }^{1}$ Institute of Pomology and Floriculture, ul. Pomologiczna 18, 96-100 Skierniewice, Poland; ${ }^{2}$ USDA Beltsville

$\langle$ Received: September 11, 1982〉

\begin{abstract}
Agrobacterium tumefaciens and cucumber, mustard and linseeds were compared as test organisms for evaluation of the biological activity of patulin. It was found that the reaction of cucumber seeds and linseed to the patulin concentrations was more pronounced than that of mustard and Agrobacterium tumefaciens. The activity of metabolites produced by Penicillium expansum was investigated with the use of cucumber seeds. As measure of activity served the percentage of radicule growth inhibition was compared with the growth in control seeds. The biological activity of the metabolites was specific for the isolates, those from apples being more active. Thirty two isolates from pears and 34 from apples were examined.
\end{abstract}

\section{INTRODUCTION}

Penicillium expansum $\langle$ Link $\rangle$ Thom, beside other Penicillium species, cause of apple and pear rot in the storage period $\langle\mathrm{B}$ o r e c k a, 1977 $\rangle$. The fungus produces mycotoxins noxious to humans, mainly patulin and trace amounts of citrinin 〈C i e g l e r et al., 1977; H a r w i g et al., 1973〉. The amount of toxins produced by the fungus'was dependent on the isolate $\langle\mathrm{P}$ y $\mathrm{te} l$ and B o r e c k a, 1984 $\rangle$ and on many external factors $\langle\mathrm{O} \mathrm{r} \mathrm{t} \mathrm{h,} \mathrm{1973 \rangle} \mathrm{such} \mathrm{as}$ temperature $\langle\mathrm{S}$ o m m e r et al., 1974; L ovet t and $\mathrm{Th}$ o m p s o n, $1978\rangle$, air composition $\langle\mathrm{L}$ o v e $\mathrm{t} t$ et al., 1975 $\rangle$, age of culture $\langle\mathrm{C}$ i e g l e r, et al., 1977 $\rangle$ and on the medium on which the fungus develops $\langle\mathrm{B} \mathrm{r}$ i a $\mathrm{n}$ et al., $1956\rangle$. The fungus produces mycotoxins into the medium on which it grows. The toxins in the soil not only inhibited a root and shoot growth of plants, but also inhibit seed germination of many plant species $\langle\mathrm{B} \mathrm{r}$ i a n, 1957; $\mathrm{P}$ a $\mathrm{t} \mathrm{r} \mathrm{i} \mathrm{c} \mathrm{k}$ et al., 1964; G o t t 1 i e b et al., 1952>.

The amount of toxins produced by the fungus is usually determined by thinlayer chromatography $\langle\mathrm{S} \mathrm{c}$ o $\mathrm{t} \mathrm{t}$ and $\mathrm{S} \mathrm{o} \mathrm{m} \mathrm{e} \mathrm{r} \mathrm{s,} \mathrm{1968 \rangle} \mathrm{as} \mathrm{a} \mathrm{precise} \mathrm{method.}$ Besides chemical analyses, biological methods are also commonly used for 
detection of the presence of toxins in the medium. They consist in revealing inhibition of the development of various living organisms by these compounds. Most frequently applied is the bacterial test $\langle\mathrm{G}$ o $\mathrm{t} \mathrm{l} \mathrm{i}$ e b and $\mathrm{S}$ i $\mathrm{m}$ i n of f, 1952; G o t $\mathrm{t} 1 \mathrm{i}$ e b et al., 1952; $\mathrm{L}$ i e u and B u 11 e r m a n, 1978; S o m$\mathrm{m}$ e $\mathrm{r}$ et al., 1974). This method consists in patulin extraction from the developed chromatogram and transfer it onto Whatman paper discs which are placed in Petri dishes with inoculated bacteria. After the incubation period the inhibition of bacterial growth assayed of patulin production. Not only bacteria, but also seeds may be used as indicators $\langle\mathrm{N}$ or s t a d t and $\mathrm{M} \mathrm{c} \mathrm{C} \mathrm{a} 11$ a, 1969 >. For this test mainly wheat seeds 〈Triticum aestivum L.> were used. The seeds with the embryo ends in the center were placed on the section of chromatogram containing patulin and next placed on sterile moist filter paper in the dishes. The presence of patulin was evaluated as the percent of elongation of the wheat roots in reference to control seeds.

The biological activity of toxins was established on the basis of changes in the development of chick embryos $\langle\mathrm{C}$ i e $\mathrm{g} \mathrm{l}$ e $\mathrm{r}$ et al., 1977 $\rangle$.

All the above mentioned methods, both quantitative and biological, are very time-consuming. A rapid and easy method is required for establishing the biological activity of metabolites particularly toxins in case of numerous isolates of the same or more other fungi used in experiment. Such an easy method is the evaluation of seed germination and root growth inhibition. It was first applied by W a 11 e $n$ et al. $\langle 1950\rangle$ with the use of pea seeds for estimation of the activity of the antibiotic action and further by $\mathrm{W} \mathrm{r} \mathrm{i} \mathrm{g} \mathrm{h} \mathrm{t}\langle 1951\rangle$ for evaluation of the toxicity of alternaric acid. The same method was used by B r i a $\mathrm{n}$ et al. $\langle 1952\rangle$ in studies on the phytotoxicity of the fungus Alternaria solani. The method of germination inhibition was also applied by $\mathrm{Dalvi}$ and $\mathrm{Sal} \mathbf{u} \mathrm{nkhe}$ $\langle 1975\rangle$ in determination of the toxicity of pesticides.

The present study was undertaken for comparison of the usefulness of several test organisms and evaluation of the biological activity of metabolites produced by various isolates of Penicillium expansum $\langle$ Link $>$ Thom.

\section{MATERIAL AND METHODS}

For determination of the activity of metabolites produced by the fungus Penicillium expansum $\langle$ Link $>$ Thom into the medium the seeds and the bacterial tests were compared. An aqueous solution of crystalline patulin was used in concentrations of $10,20,30,40$ and $50 \mu \mathrm{g} / \mathrm{ml}$. Cucumber seeds $\langle$ Cucumis sativus $\rangle$ cv. 'Wisconsin SMR 18', linseed 〈Linum usitatissimum〉 and white mustard $\langle$ Sinapsis alba $\rangle$ seeds were placed on Petri dishes $10 \mathrm{~cm}$ in diametre with filter paper saturated with $5 \mathrm{ml}$ patulin solution. The control consisted of seeds germinating in Petri dishes on filter paper imbibed with water. Each dish contained 15 seeds. The experiment was run in seven replications, each dish with 
seeds being considered a replication. The seeds were incubated for $72 \mathrm{~h}$ at $25^{\circ} \mathrm{C}$ and the lenght of the radicule was measured. The results are given as the mean radicule length calculated to one seed, account being taken of the seeds which did not germinate.

The bacterial test was performed with Agrobacterium tumefaciens $<$ Smith and Townsend $>$ Coenn, isolate no. 5, Laboratory of Phytopathology, Institute of Pomology and Floriculture in Skierniewice. This microorganism was chosen according to the investigations of $\mathrm{K} \mathrm{le} \mathrm{m} \mathrm{m} \mathrm{e} \mathrm{r} \mathrm{et} \mathrm{al.}\langle 1955\rangle$ they found it to be highly susceptible to antibiotics and among them to patulin. The test was run on bacterial culture aged $20 \mathrm{~h}$ which was added to King's medium. Three hours later filter paper discs were taken $10 \mathrm{~mm}$ in diametre, saturated with $10 \mu \mathrm{l}$ of liquid Czapek medium on which isolates nos 296 and 380 of Penicillium expansum were grown for 7 days. The amount of patulin in the discs saturated with medium from culture 296 was $29.5 \mu \mathrm{g}$ and from culture $380-28.0 \mu \mathrm{g}$. For comparison the test with cucumber seeds was performed and the same was used in further investigations on the activity of metabolites produced by various Penicillium expansum isolates.

The fungus was inoculated on the liquid Czapek medium, $25 \mathrm{ml}$ of medium in each Erlenmayer flask with the use of the discs with fungal culture aged 7 days. The cultures were kept for $72 \mathrm{~h}$ at $25^{\circ} \mathrm{C}$ and then the liquid medium from three flasks was combined and diluted with water $1: 1$. Medium from three flasks constituted one replication. Every fungal isolate was tested in three replications. With five millilitres of this fluid filter paper in the Petri dishes was saturated and cucumber seeds were placed on it. As control served dishes with liquid Czapek medium diluted in the same proportion. Dilution of the medium was indispensable since a too high concentration of nutrient component affected seed germination. The experiment was replicated 10 times, one Petri dish with 15 seeds beeing a replication. The results are given as percentage of root growth inhibition as compared with the germinating control seeds. Isolates from Penicillium expansum were tested, 32 from rotting pears stored under various conditions and 34 from apples. At the same time patulin was quantitatively determined by the method of Lovett ( $\mathrm{L} \mathrm{ove} \mathrm{t} \mathrm{t}$ and $\mathrm{Th}$ o m s o $\mathrm{n}, 1978$ ), eight isolates of Penicillium expansum with different inhibitory action on root growth of cucumber seedlings.

The results were subjected to statistical analysis of variance by comparing the mean values in Student's test. For statistical calculation the percentage values were transformed to Bliss degrees. The tables give the percentage figures.

\section{RESULTS AND DISCUSSION}

The test of the usefulness of three kinds of seed for determining the activity of metabolites excreted by Penicillium expansum used in aqueous solution of 
known concentration of crystalline patulin demonstrated that cucumber seeds and linseed were more susceptible to the action of this toxin than the mustard seeds $\langle$ Table 1$\rangle$. A low patulin concentration $\langle 10 \mu \mathrm{g} / \mathrm{ml}\rangle$ even slightly stimulated the growth of the mustard radicule, whereas the remaining concentrations of 20 , 30 and $50 \mu \mathrm{g} / \mathrm{ml}$ almost equally inhibited its development. The seeds of flax and cucumber reacted differently to various toxin concentrations. A $10 \mu \mathrm{g} / \mathrm{ml}$ concentration inhibited root growth less than did $20 \mu \mathrm{g} / \mathrm{ml}$. Somewhat smaller differences in inhibition were noted between 30 and $40 \mu \mathrm{g} / \mathrm{ml}$ patulin concentrations. Inhibition was strongest at a $50 \mu \mathrm{g} / \mathrm{ml}$ concentration.

Table 1

Comparison of various kinds of seeds for testing patulin activity

\begin{tabular}{cccc}
\hline \multirow{2}{*}{$\begin{array}{c}\text { Patulin concentration } \\
\mu \mathrm{g} / \mathrm{ml}\end{array}$} & \multicolumn{3}{c}{ Average radicule length, mm } \\
\cline { 2 - 4 } & cucumber & linseed & must ard seed \\
\hline & $11.9 \mathrm{c}$ & $16.0 \mathrm{c}$ & $18.4 \mathrm{c}$ \\
20 & $7.2 \mathrm{~b}$ & $9.3 \mathrm{~b}$ & $10.8 \mathrm{a}$ \\
30 & $6.1 \mathrm{~b}$ & $6.7 \mathrm{ab}$ & $12.0 \mathrm{a}$ \\
40 & $5.4 \mathrm{ab}$ & $4.5 \mathrm{a}$ & $13.0 \mathrm{a}$ \\
50 & $4.6 \mathrm{a}$ & $3.3 \mathrm{a}$ & $8.9 \mathrm{a}$ \\
Water & $16.5 \mathrm{~d}$ & $24.2 \mathrm{~d}$ & $14.1 \mathrm{~b}$ \\
& & & $\mathrm{~L}=0_{0} 05$ \\
\hline
\end{tabular}

Numbers followed by the same letter are not significantly different at the $0.05 \%$ level.

For comparison of living organisms in the tests for activity of patulin metabolites the bacterium Agrobacterium tumefaciens was compared with cucumber seed. The latter test proved more sensitive than the bacterial one $\langle$ Table 2〉. It should be stressed that the use of bacteria is much more tedious because of the definite requirements and age not anly of the tested fungus but of the culture used.

In further investigations of the metabolite activity of various excretions of Penicillium expansum isolates the cucumber seed test was applied. Thirty two isolates from rotting pears were tested which showed wide differences both as regards patulin content and metabolite activity, the latter activity, however, was not always dependent on the produced patulin level $\langle$ Table 3$\rangle$. It would seem, therefore, that the particular isolates differ from one another not only as regards patulin production, but also in excretion of other metabolites, probably citrinin.

The ability to produce active metabolites did not depend on the pear variety from which the fungus was isolated, nor on the conditions of storage of the fruit. The isolates from apples, however, produced among the 34 isolates a greater number of metabolites and their activity was stronger than that of products 


\section{T a ble 2}

Comparison of Agrobacterium tumefaciens and seeds of cucumber (Cucumis sativus) cv. 'Wisconsin SMR 18' in test for determination of activity of metabolites produced by' Penicillium expansum (Link) Thom

Patulin content, $\mu \mathrm{g} / \mathrm{ml}$

Agrobacterium tumefaciens

Dropped $10 \mu l$ pure patulin in conc.

$1 \mu \mathrm{g} / \mathrm{ml}$

16.9 a

Dropped $10 \mu$ liquid medium with

$P$. expansum no. 296 on disc

$20.9 \mathrm{ab}$

590

Dropped $10 \mu \mathrm{l}$ liquid medium with

$P$. expansum no. 380 on disc

24.2 b

Cucumber seeds

$5 \mathrm{ml} /$ Petri dish of liquid medium

from $P$. expansum culture no. 296

$5 \mathrm{ml} /$ Petri dish of liquid medium

from $P$. expansum culture no. 380

Chack - liquid Czapek medium

average length of radicule, $\mathrm{mm}$

2.1 a

590

$2.7 \mathrm{~b}$

560

21.5

$L=0.05$

Numbers followed by the same letter are not significantly different at the $0.05 \%$ level.

derived from pears $\langle$ Table 4$\rangle$. This feature is as yet not possible to explain. It is, namely, known that the patulin level does not depend on the medium from which the fungus was isolated $\langle\mathrm{P} \mathrm{y} \mathrm{te} 1$ and $\mathrm{B}$ or e c k a, 1984〉 for further investigations, but on the medium on which it continues its development in the test. All the isolates were cultured on the same Czapek's medium, they were evenaged and inoculated by the same method.

The methods used to date for evaluation of the biological activity of fungal metabolites require expensive and long lasting preparation as for instance chick embryos, or time-consuming chemical analyses with the use of thin-layer chromatography <S o m m e r et al., 1974; L o v e t t et al., 1975; $\mathrm{N}$ o r$\mathrm{s} \mathrm{t}$ a d t and $\mathrm{M} \mathrm{c} \mathrm{C} \mathrm{a} 11 \mathrm{a}, 1969\rangle$ or else gas chromatography. Carbon $\left[{ }^{14} \mathrm{C}\right]$ was also applied for determining the amount of patulin production by the Penicillium patulum $\langle\mathrm{N} \mathrm{i} \mathrm{p} \mathrm{and} \mathrm{C} \mathrm{h} \mathrm{u}, 1977\rangle$. It is obvious that chemical methods not only give information as to whether active toxins are produced by the fungus, but also on the kind of toxin secreted. The latter information cannot be supplied by the method of biological tests with the use of bacteria and seeds. The variability of these organisms is high, especially of bacteria which are more sensitive to external conditions. Seeds do not show variability in time, that is experiments may be performed over several months, the results being similar, unless the seeds are secondarily infected during storage by some pathogenic organism, and this obscures the picture of fungal metabolite activity. To prevent such a possibility control seeds are used and comparison of the results is possible 


\section{Table 3}

Biological activity of metabolites produced by various isolates of Penicillium expansum causing rotting of pears. Percentage of growth inhibition of radicule of cucumber cv. 'Wisconsin SMR 18' at room temperature, calculated in reference to germination on Czapek medium diluted with water $1: 1$

\begin{tabular}{|c|c|c|c|c|}
\hline $\begin{array}{c}\text { No. } \\
\text { in collection }\end{array}$ & Origin of isolate & & $\begin{array}{c}\text { Radicule growth } \\
\text { inhibition } \\
\%\end{array}$ & Patulin level \\
\hline 284 & 'Min. Lucius' cold storage & $0^{\circ} \mathrm{C}$ & $5.0 \mathrm{a}$ & \\
\hline 58 & 'Komisówka' " & $4^{\circ} \mathrm{C}$ & $5.5 \mathrm{ab}$ & $256 \mathrm{~b}$ \\
\hline $\mathbf{3 1 a}$ & 'Bonkreta Williamsa' & $0^{\circ} \mathrm{C}$ & $5.9 \mathrm{ab}$ & 130 a \\
\hline 39 & " " " & $4^{\circ} \mathrm{C}$ & $5.9 \mathrm{ab}$ & \\
\hline 282 & 'Min. Lucius' & $0^{\circ} \mathrm{C}$ & $6.2 \mathrm{ab}$ & \\
\hline 250 & 'Faworytka' & $0^{\circ} \mathrm{C}$ & $8.0 \mathrm{ab}$ & $403 \mathrm{c}$ \\
\hline 280 & 'Min. Lucius' & $0^{\circ} \mathrm{C}$ & $8.1 \mathrm{~b}$ & \\
\hline 281 & $" \quad "$ & $0^{\circ} \mathrm{C}$ & $9.7 \mathrm{bc}$ & \\
\hline 53 & 'Salisbury' & $4^{\circ} \mathrm{C}$ & $11.6 \mathrm{c}$ & \\
\hline 294 & 'Min. Lucius' & $4^{\circ} \mathrm{C}$ & $12.1 \mathrm{~cd}$ & \\
\hline 644 & 'Plebanka' & $0^{\circ} \mathrm{C}$ & $12.9 \mathrm{ed}$ & \\
\hline $\mathbf{3 0 3 a}$ & 'Bera Hardy' & $4^{\circ} \mathrm{C}$ & $13.1 \mathrm{~cd}$ & \\
\hline 57 & 'Komisówka' & $4^{\circ} \mathrm{C}$ & $14.0 \mathrm{~cd}$ & $168 \mathrm{ab}$ \\
\hline 263 & 'Bera Hardy' & $0^{\circ} \mathrm{C}$ & $14.3 \mathrm{~cd}$ & \\
\hline 272 & 'Min. Lucius' & $0^{\circ} \mathrm{C}$ & $14.4 \mathrm{~cd}$ & \\
\hline 248 & 'Faworytka' & $0^{\circ} \mathrm{C}$ & $14.5 \mathrm{~cd}$ & \\
\hline 278 & 'Min. Lucius' & $0^{\circ} \mathrm{C}$ & $14.5 \mathrm{~cd}$ & \\
\hline 364 & 'Plebanka' storage & & $14.5 \mathrm{~cd}$ & \\
\hline 259 & 'Bera Hardy' cold storage & $0^{\circ} \mathrm{C}$ & $14.6 \mathrm{~cd}$ & \\
\hline 36 & 'Bonkreta Williamsa'" & $0^{\circ} \mathrm{C}$ & $14.7 \mathrm{~cd}$ & \\
\hline 38 & $" \quad "$ & $0^{\circ} \mathrm{C}$ & $14.7 \mathrm{~cd}$ & $520 \mathrm{~d}$ \\
\hline 221 & 'Lukasówka' & $0^{\circ} \mathrm{E}$ & $15.5 \mathrm{~cd}$ & 148 a \\
\hline 244 & 'Faworytka' & $0^{\circ} \mathrm{C}$ & $16.2 \mathrm{~d}$ & \\
\hline 253 & 'Plebanka' & $4^{\circ} \mathrm{C}$ & $17.0 \mathrm{~d}$ & \\
\hline 54 & 'Salisbury' & $4^{\circ} \mathrm{C}$ & $15.6 \mathrm{~d}$ & \\
\hline 227 & 'Lukasówka' & $4^{\circ} \mathrm{C}$ & $18.3 \mathrm{de}$ & \\
\hline 374 & 'Bera Hardy' & $4^{\circ} \mathrm{C}$ & $18.6 \mathrm{de}$ & \\
\hline 373 & 'Plebanka' & & $19.2 \mathrm{de}$ & \\
\hline 380 & 'Plebanka' "' & & $19.8 \mathrm{de}$ & $560 d$ \\
\hline 298 & 'Komisówka' cold storage & $0^{\circ} \mathrm{C}$ & $20.0 \mathrm{de}$ & $590 d$ \\
\hline 240 & 'Lukasowka' " " & $4^{\circ} \mathrm{C}$ & $23.0 \mathrm{e}$ & \\
\hline \multirow[t]{2}{*}{296} & 'Min. Lucius' & $4^{\circ} \mathrm{C}$ & $24.0 \mathrm{e}$ & \\
\hline & & & & $\mathrm{L}=\mathbf{0 . 0 5}$ \\
\hline
\end{tabular}
level.

Numbers followed by the same letter are not significantly different at the $0.05 \%$

in this case by calculating the percentage of germination inhibition in reference to the controls. The biological method with the use of seeds does not answer the question what metabolites are produced by the given fungal isolate because many of them have inhibitory properties towards seeds. In the studies on Penicillium expansum the metabolites have been rather accurately described by numerous 
T a b 1 e 4

Biological activity of metabolites produced by various isolates of Penicilium expansum causing rotting of apples. Percentage of growth inhibition of radicule of cucumber cv. 'Wisconsin SMR 18' at room temperature, calculated in reference to germination on Czapek medium diluted with water $1: 1$

No. in collection

Origin of isolate

Percent of radicule growth inhibition

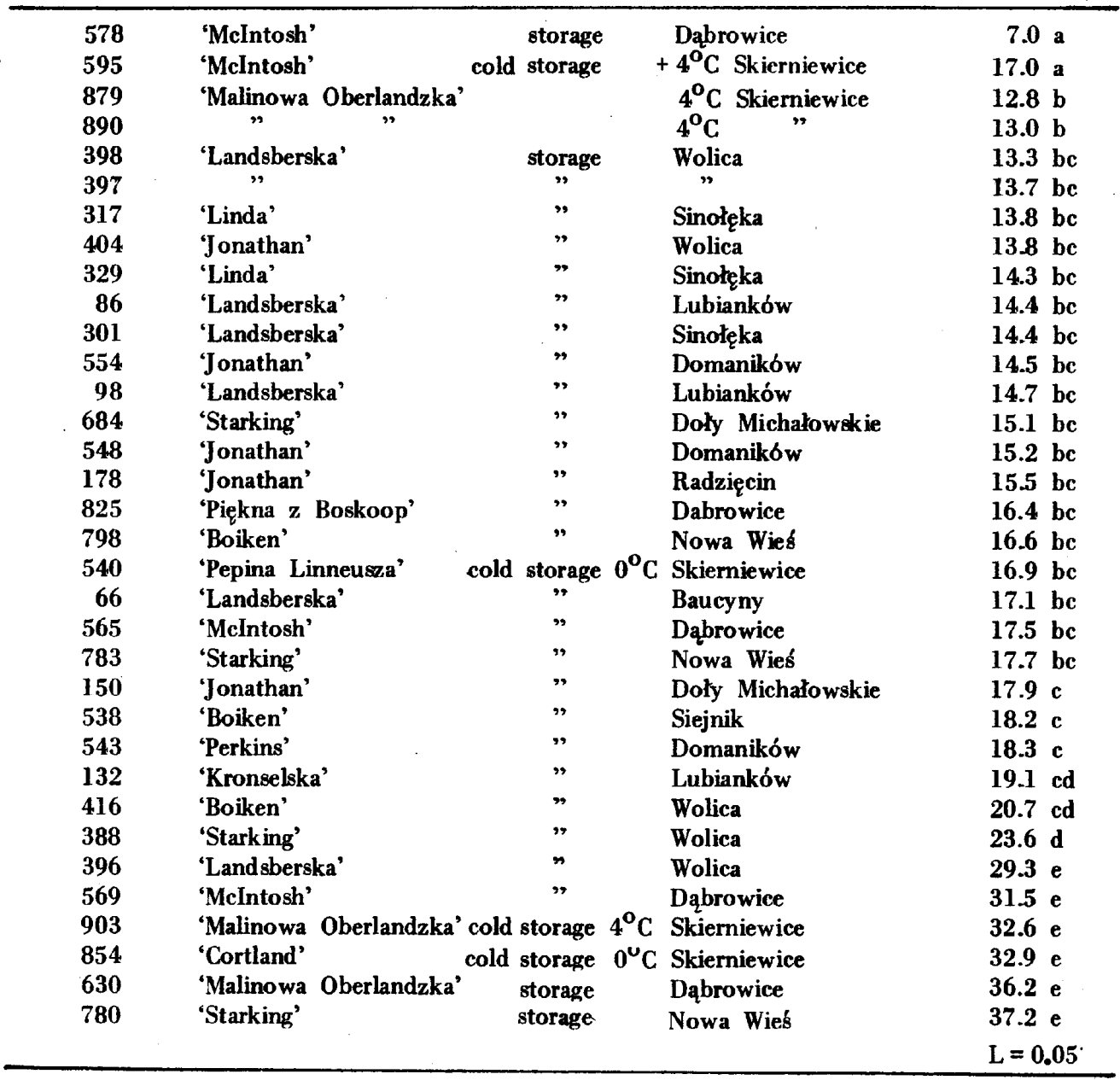

Numbers followed by the same letter are not significantly different at the $0.05 \%$ level.

investigators, therefore, the biological methods gave satisfactory results. It would nevertheless, be useful to continue studies on the identification of metabolites produced by this genus of fungi. 
We thank Dr. D. K. S a $1 \mathrm{u} \mathrm{n} \mathrm{k}$ h e of the Utah State University, Logan USA for the suggestion of using cucumber seeds in these experiments.

\section{REFERENCES}

B o r e c k a H., 1977. Fungi of the genus Penicillium on apples and pears during storage period. Acta Agrobot. 32: 213-227.

B ri a n P. W., E 1 s o n G. W., H e $\mathrm{m} m$ in $g$ H. G., W r i g h t J. M., 1952. The phytotoxic properties of alternaric acid in relation to the etiology of plant diseases caused by Alternaria solani 〈Ell and Mart〉 Jones and Cront. Ann. Appl. Biol. 39: 308-321.

B ri a n P. W., E l s o n G. W., L o w e D., 1956. Production of patulin in apple fruits by Penicillium expansum. Nature 178: 263.

B r i a n P. W., 1957. Effects of antibiotics on plants. Ann. Rev. Plant Physiol. 8: 413-426.

Ci e g l e r A., V e s o n d e r R.F., J a c $t$ i o $n$ L. K., 1977. Production and biological activity of patulin and citrinin from Penicillium expansum. Appl. Env. Microbiol. 33: 1004-1006.

D a 1 v i R. R., S a 1 u n k h e D. K., 1975. Toxicological implications of pesticides: their toxic effects on seeds of food plants. Toxicology 3: 269-285.

$\mathrm{G}$ o t $\mathrm{tl}$ i e b D., S i m i n of $f$ P., 1952. The production and role of antibiotics in the soil. II. Chloromycetin. Phytopath. 42: 91-97.

G o $t \mathrm{t} l$ i e b D., S i m i n of $f$ P., M a $\mathrm{r} t$ i $\mathrm{n} \mathrm{M.,} \mathrm{1952.} \mathrm{The} \mathrm{production} \mathrm{and} \mathrm{role} \mathrm{of} \mathrm{antibiotics}$ in soil. IV. Actodione and clavacin. Phytopath. 42: 493-496.

H a r w i g J., C h e n Y.K., K e n n e d y B.P.C., S c o t t P. M., 1973. Occurrence of patulin and patulin producing strains of Penicillium expansum in natural rots of apple in Canada. Can. Inst. Food Sci. Technol. 6: 22-25.

K l e m m e r H. W., R i k e r A. J., A 11 e n O. N., 1955. Inhibition of crown gall by selected antibiotics. Phytopath. 45: 618-625.

L i e u F.Y., B u 11 e $\mathrm{r}$ m a n L. B., 1978. Binding of patulin and penicillic acid to glutathione and cysteine and toxicity of the resulting adducts. Milchwissenschaft 33: 16-20.

L o ve t t J., Th o mps o n R. G., B o u t i n B. K., 1975. Trimming as a means removing patulin from fungus-rotted apples. J. of the AOAC 58: 909-911.

L o vet t J., Th o m p s o n R. G., 1978. Patulin production by species of Aspergillus and Penicillium at $1.7,1.2$ and $12.8^{\circ} \mathrm{C}$. J. of Food Protection 41: 195-197.

$\mathrm{N}$ i p W. K., $\mathrm{C}$ h u E. S., 1977. Production of $\left[{ }^{14} \mathrm{C}\right]$ patulin by Penicillium patulum. Appl. Env. Microbiol. 33: 814-816.

N o r s t a d t F. A., M c C a 11 a T. M., 1969. Penicillium urticae Bainier enumeration in soils. Plant and Soil 30: 129-133.

O r th R., 1973. Bildungsbedingungen einiger carcinogener Mycotoxine Zeitsch. Leb. UntersForsch. 151: 267-273.

P a t r i c Z. A., T o u s s o n T. A., K o c h L. W., 1964. Effect of crop residue decomposition products on plant roots. Ann. Rev. of Phytopath. 2: 267-292.

P y t e 1 M., B o r e c k a H., 1984. Wytwarzanie patuliny przez różne izolaty grzyba Penicillium expansum 〈Link〉 Thom. Acta Agrobot. 35: 235-242.

$\mathrm{S} c$ o $t \mathrm{t}$ P. M., S o m e r s E., 1968. Stability of patulin and penicillic acid in fruit juices and flour. J. Agr. Food Chem. 15: 483-485.

S o m m e r N. F., B u cha n a n J. R., F or t l a ge R. J., 1974. Production of patulin by Penicillium expansum. Appl. Microbiol. 28: 589-593.

W a 1 l e $n$ V.R., S u t $t$ o n M.D., S k o $1 \mathrm{k}$ o A. J., 1950. The effect of actidione on the growth of certain pathogenic fungi and on the germination of pea seed. Phytopath. 156-160.

W r i g h t J. M., 1951. Phytotoxic effects of some antibiotics. Ann. Bot. London N. S. 15: 493-500. 


\section{OCENA AKTYWNOŚCI BIOLOGICZNEJ METABOLITÓW WYTWARZANYCH \\ PRZEZ RÓŻNE IZOLATY PENICILLIUM EXPANSUM 〈LINK〉 THOM}

\section{Streszczen i e}

Porównano przydatność Agrobacterium tumefaciens oraz nasion ogórka, gorczycy i lnu, jako organizmów testowych w ocenie aktywności biologicznej patuliny. Stwierdzono, że nasiona ogórka i lnu wyraźniej niż gorczyca i Agrobacterium tumefaciens reagowały na stężenie patuliny.

Aktywność metabolitów wytwarzanych przez Penicillium expansum badano przy użyciu nasion ogórka. Miarą aktywności był procent zahamowania wzrostu korzonka 〈radicula〉w stosunku do jego wzrostu u nasion kontrolnych. Stwierdzono, że aktywność biologiczna metabolitów była cechą izolatu, przy czym izolaty $\mathrm{z}$ jabłek wydzielały bardziej aktywne metabolity. Zbadano 32 izolaty pochodzące $z$ gruszek i 34 izolaty z jabłek. 